\title{
Isolation, Definition and Chemical Control some of the Bacteria that Cause Contamination of Wall Paintings in Caves
}

\section{Gorj M. A E1 Fatma1*, Aisha M. A.1 and Maznah W.0.2}

${ }^{1} \mathrm{Al}$ Jabal Al Gharbi University. Faculty of science, Zoology Department. Azintan - Libya.

2School of Biological Sciences, University Sains Malaysia 11800 Penang. Malaysia.

\section{A B S T R A C T}

Background: Caves are unique natural features and habitats where specialized organisms grow. One of the world's main concerns is that of the conservation and preservation of our cultural heritage, including rock art and wall paintings within caves.

Methods: This study was conducted by collecting the samples scraped from wall surfaces at 19 different location in painted caves of Niah cave, Sarawak, and Tempurung cave, Perak. Morphospecies identification and genomic DNA polymorphisms were used to identify the two strains of bacteria. The growth was controlled chemical method using sodium hypochlorite (NaOCl), $\mathrm{Calcium}$ hypochlorite $\mathrm{Ca}(\mathrm{OCl})_{2}$ and hydrogen peroxide $\left(\mathrm{H}_{2} \mathrm{O}_{2}\right)$.

Results: Morphospecies identification was carried out using a light microscopy and scanning electron microscopy (SEM), both the bacteria, bacteria I and bacteria II were isolated from the soil samples and were Gram-negative bacteria. Based on BLAST search, bacteria I showed 100\% with Stenotrophomonas sp (NR 024708.1), and bacteria II showed 100\% with Cryptococcus liquefaciens (NR 043289. 1). The growth was controlled chemical method using sodium hypochlorite $(\mathrm{NaOCl}), \mathrm{Calcium}$ hypochlorite $\mathrm{Ca}(\mathrm{OCl})_{2}$ and hydrogen peroxide $\left(\mathrm{H}_{2} \mathrm{O}_{2}\right)$. The laboratory studies showed that three chemical were effectively eliminated colonies/cells of the both bacteria compared to the colonies found on the control pate this study.

Keywords: - Niah cave, Tempurung cave, Stenotrophomonas sp, Cryptococcus liquefaciens.

\begin{tabular}{l}
\hline A R T I C L E I N F O: Received 11 April 2019; Review Completed 22 May 2019; Accepted 08 June 2019; Available online 15 Oct. 2019 \\
Cite this article as: \\
Gorj M. A El Fatma, Aisha M. A. Maznah W.O., Isolation, Definition and Chemical Control some of the Bacteria that Cause \\
Contamination of Wall Paintings in Caves, Asian Journal of Pharmaceutical Research and Development. 2019; 7(5):06- \\
11, DOI: http://dx.doi.org/10.22270/ajprd.v7i5.507
\end{tabular}

\section{INTRODUCTION}

$\mathrm{M}$ alaysia is blessed with a large number of natural structures, including caves. These caves are huddled within Malaysia "s rich rainforests and mangrove forests. These caves have become popular archaeological sites as the artefacts found in them can be traced to 40,000 years back, and ancient rock paintings can be found in these caves. There are also other natural attractions such as massive stalagmites and stalactites, which draw the attention of researchers ${ }^{1}$. In Malaysia, Tempurung cave, which is located in Gopeng, Perak; the painted cave, located in the Niah National Park, Sarawak. In caves, different habitats are populated by different microorganisms such as bacteria, fungi, algae and protozoa. It is a known fact that microbes are usually identified in water bodies, rocky surfaces, on sediments and in guano. Another important group of microorganisms are those which develop through different types of interaction with troglobitic animals, e.g. epibionts and parasites in caves ${ }^{2}$.

Bacteria are single-celled, prokaryote microorganisms normally a few micrometres in length and have a wide range of forms, from spheres to rods and spirals ${ }^{3}$. They can be responsible for the destruction of cultural heritages. Bacterial isolates from indoor environments like caves, churches, museums and chapels, are often attributed to the genus Bacillus or are part of the bacterial population of known or unknown species ${ }^{4,5}$, or are Proteobacteria or Actinobacteria. In a larger study to assess microbial communities in the 
UNESCO World Heritage Naracoorte Caves ${ }^{6}$, it was found that bacteria play critical roles in the formation and biogeochemical cycles of caves, with adverse effects on the environment in the caves. Also visiting bat caves. May lead to infection of cases may occur because of the disturbance of soil contaminated with $H$. capsulatum ${ }^{7}$. Bacterial isolates have commonly been ascribed to the genus Bacillus. A study by ${ }^{8}$ used DNA-based techniques to characterize the bacterial community and the study revealed that a significant part of the bacterial population is made up of unknown species.

Malaysia enjoys wonderful caves of beauty and breadth, but these natural resources are exposed to the growth of undesirable microorganisms, which grow on the walls and ceilings of all caves, due to naturally occurring levels of nutrients and moisture that are sufficient to support the growth of undesirable microorganisms. This growth degrades the natural beauty of cave walls, and threatens their archaeological value. Therefore, an attempt should be made to eliminate these undesirable microorganisms. Objective of the study to isolation and identify of the bacteria inhabiting the cave walls of Tempurung and Niah caves that cause damage to the rock art and wall painting.

\section{MATERIALS AND METHODS}

Study Area: The area selected for this study was the Niah Caves, situated in Miri, Sarawak to the north of Borneo, Malaysia (3.802 N-113.773 E). Tempurung Cave the Tempurung Cave is situated in Gopeng, Perak.

\section{Isolation, purification and identification of bacteria}

Isolation of bacteria, the samples were passed through a sieve $(1.7 \mathrm{~mm}$ mesh) to get rid of large pieces of debris and vegetation. Five grams of the samples from wall paintings was added to $100 \mathrm{ml}$ of nutrient broth (NB) in sterilized 250 $\mathrm{ml}$ Erlenmeyer flasks. The cultures were incubated overnight in a shaking water bath at $37^{\circ} \mathrm{C}(24 \mathrm{~h})$ at $180 \mathrm{rpm}$. The bacteria were originally isolated by plating dilutions of the sample in (NB). One $\mathrm{ml}$ portions from each dilution, ranging from $10^{-1}$ to $10^{-5}$, were spread onto the Nutrient Agar (NA) and incubated at $37{ }^{\circ} \mathrm{C}$ for 48 hours. The developed colonies were picked and purified by streaking them on the NA plates. The bacterial isolates were kept on the NA plates at $4{ }^{\circ} \mathrm{C}$ and re-cultured every 3 weeks ${ }^{9}$.

\section{Observation of the isolated bacteria}

\section{Observation using light microscopy}

In order to examine microorganisms under a light microscopy at magnification of 10x, 20x, 40x or/and 100x, a drop of solution containing the bacteria, or a single colony (picked up using a sterile toothpick or loop) was placed on a clean microscope slide. The cover slip was lowered and tilted at an angle, until the lower edge touched the slide at the edge of the microorganism solution drop ${ }^{10}$.

Gram staining was conducted; The Gram stain procedure enables bacteria to retain the colour of the stains, based on the differences in the chemical and physical properties of the cell wall. Gram-positive results in a purple-blue colour, while Gram-negative results in a pink-red colour. Observations of live microorganism cells on the worksheet include the nucleus, colour, size and cell shapes ${ }^{11-14}$.

\section{Observation using scanning electron microscopy (SEM)}

The hexamethyldisilazane (HMDS method) method was used to prepare the cells of bacteria grown in the liquid media. The samples were centrifuged $4,000 \mathrm{rpm}$ to obtain pellet. After centrifugation, the supernatant was discarded and the pellets were re-suspended using the McDowellTrump fixative, which was prepared in $0.1 \mathrm{M}$ phosphate buffer ( $\mathrm{pH} \mathrm{7.2)} \mathrm{for} \mathrm{at} \mathrm{least} 2$ hours. The samples were centrifuged again and the pellets obtained were transferred into Eppendorf tubes. The pellets were then re-suspended in $0.1 \mathrm{M}$ phosphate buffer (buffer wash 1). Similar steps were repeated for buffer wash 2 . After buffer wash 2, the pellets were re-suspended into osmium tetroxide prepared in the phosphate buffer for 1 hour (post-fixation). The post-fixation process was repeated twice, followed by a dehydration process with $50 \%$ ethanol for 10 minutes, $75 \%$ ethanol for 10 minutes, $95 \%$ ethanol for 10 minutes, $100 \%$ ethanol for 10 minutes (x2), and Hexamethyldisilazane (HMDS) for 10 minutes. After dehydration, the HMDS was transferred from the tube, and the tube with the cells was left in a desiccator under room temperature. Then the dried cells were mounted onto an SEM specimen stub with double-sided sticky tape (or silver paint). The specimen was covered with gold, gold/palladium, chromium or carbon, and observed under the SEM ${ }^{15}$.

\section{Genomic DNA extraction}

For DNA extraction, phenol chloroform extraction method was used. In this method, $50 \mathrm{ml}$ of the culture pellet from the exponential phase was transferred into an Eppendorf tube and centrifuged at $14000 \mathrm{rpm}$ for 10 minutes. The supernatant was discarded and the pellet was re-suspended with $500 \mu \mathrm{L}$ of Sucrose Tris EDTA (STE) solution, $\mathrm{pH}$ 7.4. Then, $50 \mu \mathrm{L}$ of $10 \%$ sodium dedocyl sulphate (SDS, also called sodium dodecyl sulphate) was added and incubated at $37{ }^{\circ} \mathrm{C}$ in a water bath for one hour. After that, $3 \mu \mathrm{L}$ of proteinase $\mathrm{K}$ was added and incubated again under the same conditions $^{16,17}$. Next, phenol: chloroform extraction was performed by adding equal volumes of phenol and chloroform before centrifuged at $14000 \mathrm{rpm}$ for 10 minutes. The bottom layer was discarded and the process was repeated three times. Then, chloroform extraction was performed by adding an equal volume of chloroform and centrifuged at $14000 \mathrm{rpm}$ for 10 minutes. The bottom layer was discarded and the process was repeated twice. Then, the upper layer was precipitated with absolute ethanol and was incubated overnight at $-20{ }^{\circ} \mathrm{C}$. The Eppendorf tube was centrifuged at $14000 \mathrm{rpm}$ for 10 minutes. The pellet was re-suspended with $70 \%$ ethanol and centrifuged at $14000 \mathrm{rpm}$ for 10 minutes. The supernatant was discarded and the pellet was washed with $70 \%$ ethanol. The tube was given a short spin and the supernatant was discarded. The DNA pellet was re-dissolved in $30 \mu \mathrm{L}$ of TE buffer/ $\mathrm{dH}_{2} \mathrm{O}$. It was stored in small aliquots at $4{ }^{\circ} \mathrm{C}$ until further use.

\section{PCR Amplification of ribosomal DNA and sequencing}

The amplification of $16 \mathrm{~S}$ was performed for bacteria was carried using a set of $16 \mathrm{~S}$ primers $\left(16 \mathrm{SF} 5^{\text {ee }}\right.$ 
TNANACATGCAAGTCGAGCG 3", 16SR $5^{\text {"e }}$

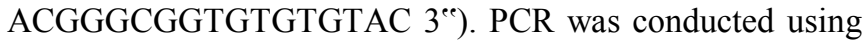
$50 \mu \mathrm{L}$ reaction containing $0.5 \mu \mathrm{L}$ of DNA template, $1.5 \mu \mathrm{L}$ of $50 \mathrm{mM}$ Magnesium chloride, $5.0 \mu \mathrm{L}$ of $10 \mathrm{X}$ PCR buffer, $1.0 \mu \mathrm{L}$ of $10 \mathrm{mM}$ dNTP mix, $2 \mu \mathrm{L}$ of 25 pmole of $16 \mathrm{~S}$ primers, $2 \mu \mathrm{L}$ of $5 \mu / \mu \mathrm{L}$ Taq DNA polymerase and $37.37 \mu \mathrm{L}$ of deionized distilled water to make up a total volume of $50 \mu \mathrm{L}$. The PCR amplification was performed as follows: 5 minutes for initial denaturation at $94{ }^{\circ} \mathrm{C}$, followed by 30 cycles of denaturation at $94{ }^{\circ} \mathrm{C}$ for 45 seconds, annealing at $55^{\circ} \mathrm{C}$ for 30 seconds and extension at $72{ }^{\circ} \mathrm{C}$ for 1 minute 40 seconds, and a final extension at $72{ }^{\circ} \mathrm{C}$ for 5 minutes. The PCR products were then checked on $1 \%$ agarose gel. The desired bands were excised from the agarose gel and purified by using the Intron Fragment and DNA Gel Extraction Kit (Intron, Korea) according to the manufactureres instructions. The purified products were sent to a service provider for DNA sequencing.

\section{Pair- Wise Sequence Alignment}

The sequences of bacteria were aligned using Clustal W included in Molecular Evolution Genetic Analysis (MEGA $\mathrm{S})$, and the consensus sequences were used to compare with other sequences in the Gen Bank (http://www.ncbi.nlm.nih.gov /genbank/) using BLAST.

\section{Preparation of chemical agents to control the growth of bacteria}

Three chemical agents used as disinfectant were tested, which were sodium hypochlorite $(\mathrm{NaOCl})$, Calcium hypochlorite $\mathrm{Ca}(\mathrm{OCl})_{2}$ and hydrogen peroxide $\left(\mathrm{H}_{2} \mathrm{O}_{2}\right)$. The solution was diluted to give accurate concentrations of 0,5 , $10,15,30$ and $60 \%$ to be tested against the bacteria. Table 1 shows how concentrations of chemicals $(\%)$ were prepared.

Table 1: Preparation of chemical concentrations $(\%)$ (Sodium hypochlorite $(\mathrm{NaOCl}), \mathrm{Calcium}$ hypochlorite $\mathrm{Ca}(\mathrm{OCl})_{2}$ and hydrogen peroxide $\left(\mathrm{H}_{2} \mathrm{O}_{2}\right)$

\begin{tabular}{|c|c|c|c|c|}
\hline $0 \%$ & $5 \%$ & $15 \%$ & $30 \%$ & $60 \%$ \\
\hline $\begin{array}{l}100 \mathrm{ml} \text { YM broth with } \\
\text { culture from exponential } \\
\text { phase }\end{array}$ & $\begin{array}{l}5 \mathrm{ml} \text { chemical agents }+95 \\
\mathrm{ml} \text { nutrient broth }(\mathrm{NB}) \text { with } \\
\text { culture from exponential } \\
\text { phase }\end{array}$ & $\begin{array}{l}15 \mathrm{ml} \text { chemical agents }+85 \\
\text { ml nutrient broth }(\mathrm{NB}) \text { with } \\
\text { culture from exponential } \\
\text { phase }\end{array}$ & $\begin{array}{l}30 \mathrm{ml} \text { chemical agents }+70 \\
\text { ml nutrient broth }(\mathrm{NB}) \text { with } \\
\text { culture from exponential } \\
\text { phase }\end{array}$ & $\begin{array}{l}60 \mathrm{ml} \text { chemical agents }+40 \\
\text { ml nutrient broth (NB) with } \\
\text { culture from exponential } \\
\text { phase }\end{array}$ \\
\hline
\end{tabular}

Preparation of bacteria inoculum and exposure to test chemical

1. Test media: NB and NA were used for cultivation of bacteria.

2. Inoculum preparation: Four or five colonies were transferred to $100 \mathrm{ml}$ of specific media to obtain a suspension equivalent to the turbidity of a McFarland 0.5 standard, which can be used to determine approximate numbers of bacteria in the experimental tubes.

3. Incubation: Incubation took place on a mechanical shaker at $35^{\circ} \mathrm{C}$ until the suspension was visibly turbid (the growing microorganisms were not allowed to grow to produce heavy turbidity). This preparation should correspond to an early to mid-logarithmic growth phase for more rapidly growing bacteria. The growth phase was confirmed by measuring the growth by observing the spectrophotometer at $600 \mathrm{~nm}$ wavelength for bacteria.

4. Preparation of chemical reagent working concentrations: Referring to Table.1, $5 \mathrm{ml}$ of a chemical reagents $\left[(\mathrm{NaOCl}), \mathrm{Ca}(\mathrm{OCl})_{2}\right.$ or $\left.\mathrm{H}_{2} \mathrm{O}_{2}\right]$ was added to 95 $\mathrm{ml}$ of the media with culture from the exponential phase $\left(6 \times 10^{5} \mathrm{cfu} / \mathrm{ml}\right)$ to obtain a concentration of $5 \% ; 15 \mathrm{ml}$ of a chemical agent $\left[\left(\mathrm{NaOCl}, \mathrm{Ca}(\mathrm{OCl})_{2}\right.\right.$, or $\left.\left.\mathrm{H}_{2} \mathrm{O}_{2}\right)\right]$ was added to $85 \mathrm{ml}$ of specific media with culture from the exponential phase $\left(6 \times 10^{5} \mathrm{cfu} / \mathrm{mL}\right)$ to get a concentration of $15 \% ; 30 \mathrm{ml}$ of a chemical agent was added to $70 \%$ of the media with culture from the exponential phase $\left(6 \times 10^{5} \mathrm{cfu} / \mathrm{mL}\right)$ to obtain a concentration of $30 \%$, and 40 $\mathrm{ml}$ of a chemical agent was added to $60 \%$ of specific media with culture from the exponential phase $\left(6 \times 10^{5} \mathrm{cfu} / \mathrm{mL}\right)$ to obtain a concentration of $60 \%$. The control sample comprised $100 \%$ of specific media without chemicals, inoculated with culture from the exponential phase $\left(6 \times 10^{5} \mathrm{cfu} / \mathrm{ml}\right)$. The final bacteria concentration for the experiment was approximately $6 \times 10^{5} \mathrm{cfu} / \mathrm{ml}$.

5. Chemical agent working concentrations $(0,5,15,30$ or $60 \%$ ), with approximately $6 \times 10^{5} \mathrm{cfu} / \mathrm{ml}$ of bacteria in the test tubes, were left for an incubation period up to 120 minutes.

6. After $1,2,5,10,15,30,60,75$ and 120 minutes of incubation, $30 \mu \mathrm{L}$ of the chemical agent working concentrations containing the bacteria in the test tubes were transferred into an agar plate (with specific media).

7. $30 \mu l$ of the chemical agent working concentrations was transferred to agar after every exposure. Then all the Petri dishes were incubated for 24 to 48 hours at $35^{\circ} \mathrm{C}$ for the cultures to grow and the cfu per ml versus time graph was plotted. Then the colonies on each of the serial dilution plates showing 30 to $300 \mathrm{cfu}$ were counted. The data were recorded on a worksheet.

8. Statistical analysis: A scatter chart was inserted to compare pairs of values. The data were analyzed using a general linear model (univariate) (SPSS, 20) to test for possible significant differences in the independent variables (concentration, time and chemical agents or physical control). A simple main effects analysis followed by Tukey"s multiple comparison test (Tukey's HSD, honest significant difference test) were utilized, when appropriate, as post-hoc procedures to follow up on the significant main effect and interactions. A p-value of less than $0.05(\mathrm{P}<0.05)$ was considered significant ${ }^{18-21}$. 


\section{RESULTS}

\section{Isolation and Identification of bacteria}

Two types of bacteria, Bacteria I and Bacteria II were isolated from the Malaysian caves. Both the bacteria were

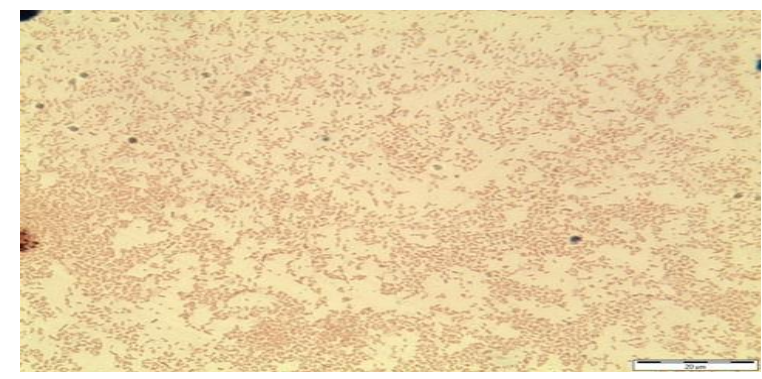

Plate 1: Bacteria I: under light microscope a genus of Gram-negative bacteria.

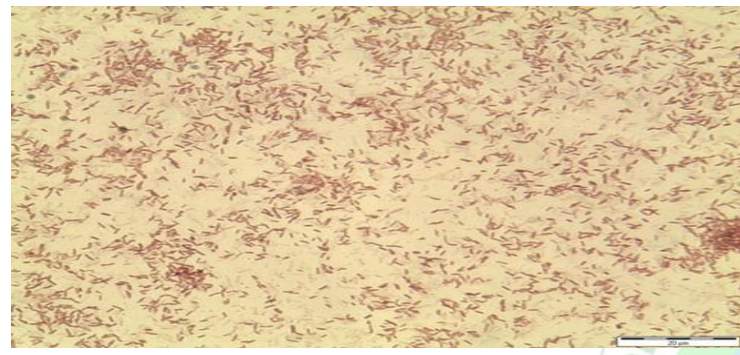

Plate 3: Bacteria II: under light Microscope, a Gram-negative.

\section{Molecular characterization}

The cells of bacteria were harvested through centrifugation and their genomic DNA was extracted (in duplicate). Samples with DNA bands that showed high molecular weights and brightness were selected for PCR analysis. The molecular weights obtained for PCR products were 1364bp for Bacteria I, 1372bp for Bacteria II. According to BLAST search, bacteria I showed $100 \%$ with Stenotrophomonas sp (NR 024708. 1), bacteria II showed $100 \%$ with Cryptococcus liquefaciens (NR 043289. 1). isolated from the soil samples and were Gram-negative bacteria. Morphospecies bacteria I is a genus of Gramnegative bacteria (Plates 1 and 2), Morphospecies bacteria II is a genus of Gram-negative bacteria (Plate 3 and 4).

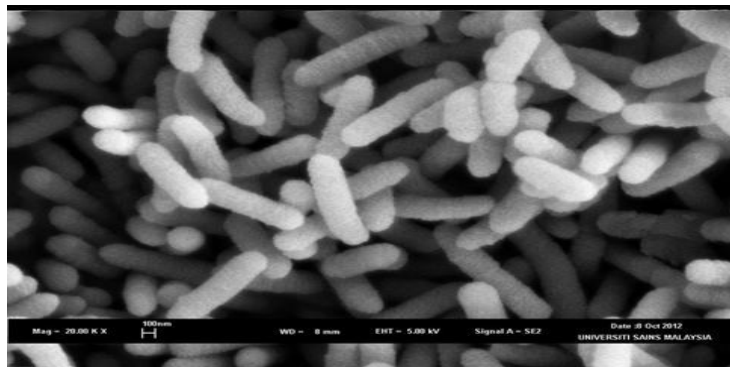

Plate 2: Bacteria I: under SEM observation.

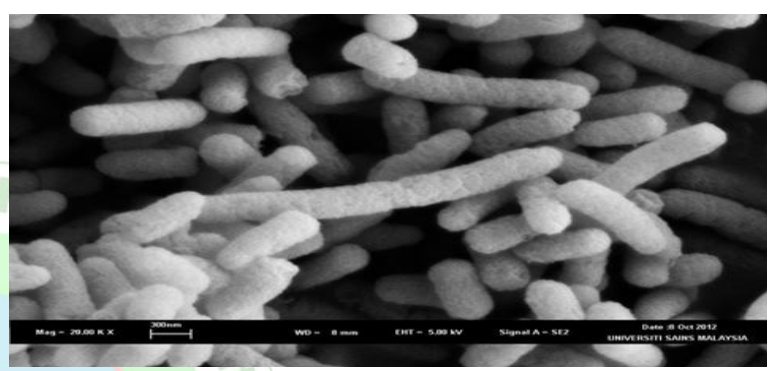

Plate 4: Bacteria II: under SEM observation

\section{Chemical Control}

Three disinfectant, $\mathrm{NaOCl}, \mathrm{Ca}(\mathrm{OCl})_{2}$ and $\mathrm{H}_{2} \mathrm{O}_{2}$ were evaluated for their ability and effectiveness in controlling growth of the bacteria in the present study.

\section{Sodium hypochlorite $(\mathrm{NaOCl})$}

Results showed that $\mathrm{NaOCl}$ reduced the number of bacteria to zero in all concentrations (Figure 1) at all exposure times. Exposure to $5 \% \mathrm{NaOCl}$ concentration for one minute was enough to eliminate Stenotrophomonas sp. and Pseudomonas aeruginosa.

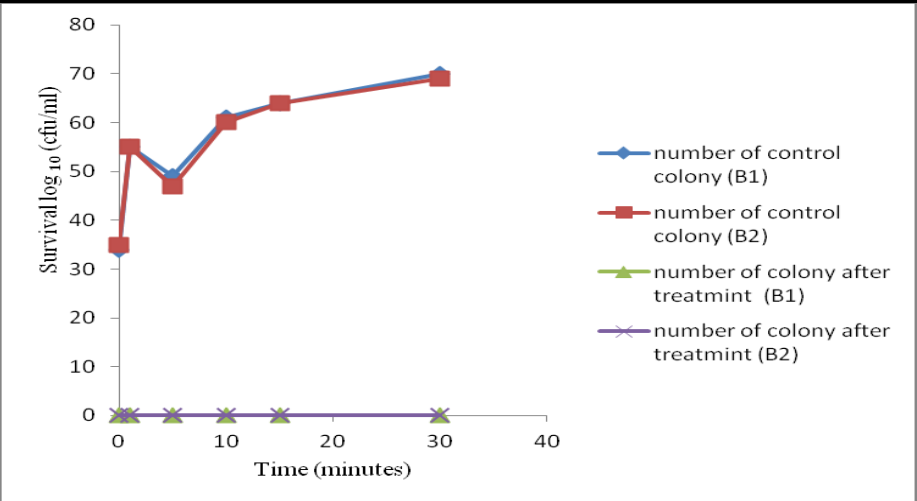

Figure 1: There was no growth of bacteria after exposure to sodium hypochlorite ( $\mathrm{NaOCl}$ ) Stenotrophomonassp (B1). And Pseudomonas aeruginosa (B2).

\section{Calcium hypochlorite $\mathrm{Ca}(\mathrm{OCl})_{2}$}

Growth of Stenotrophomonas sp. and Pseudomonas aeruginosa were reduced to zero for all concentrations tested at all exposure duration (Figure 2). 


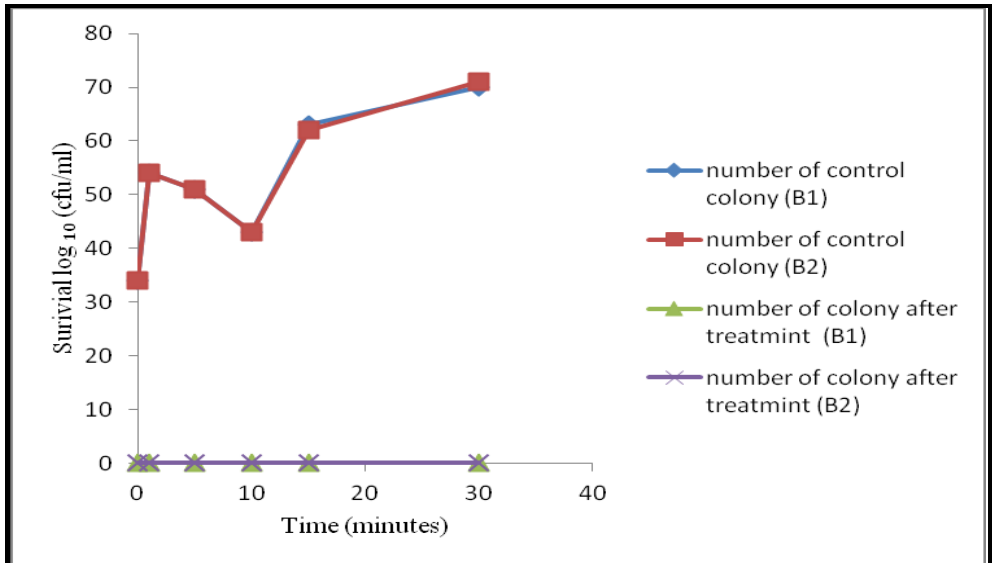

Figure 2: there was no growth of bacteria Stenotrophomonas sp. (B1) and Pseudomonas aeruginosa (B2) after exposure to calcium hypochlorite Ca (OCl) 2 .

\section{Hydrogen peroxide $\left(\mathrm{H}_{2} \mathrm{O}_{2}\right)$}

The results showed that $\mathrm{H}_{2} \mathrm{O}_{2}$ effectively reduced the number of bacteria to zero at all concentrations (Figure 3). Treatment with $5 \%$ concentration for one minute was enough to eliminate colonies of Stenotrophomonas sp. and P. aeruginosa.

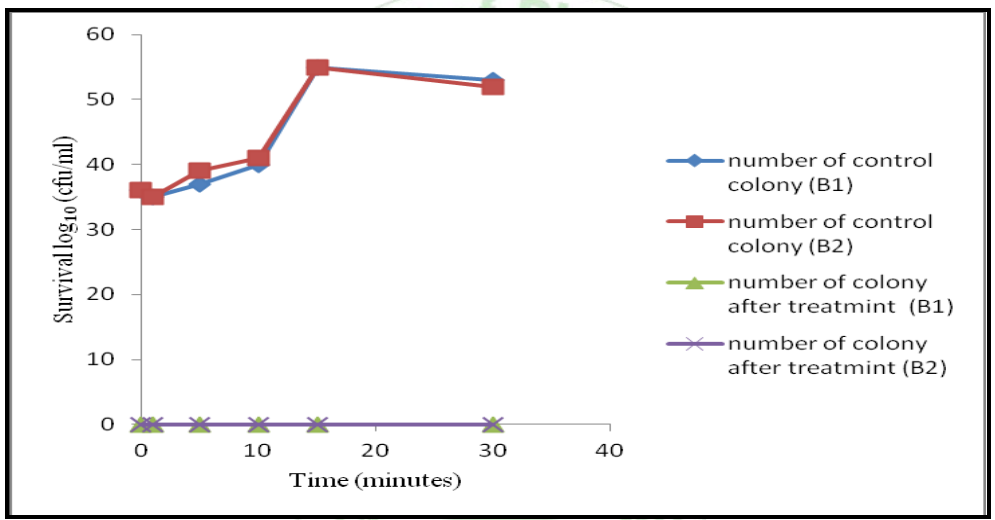

Figure 3: There was no growth of bacteria Stenotrophomonas sp. (B1) and Pseudomonas aeruginosa (B2) after exposure to hydrogen peroxide $\left(\mathrm{H}_{2} \mathrm{O}_{2}\right)$.

\section{DISCUSSION}

A cave is a place characterized by low temperature and humidity, which is more or less constant throughout the year 22. That made Tempurung and Niah Caves a suitable environment for the invasion of bacteria that appear as a result of the presence of bats, insects and some reptiles that live in the cave. The occurrence of Gram-negative bacteria in the cave such as Stenotrophomonas sp. and Pseudomonas sp. was also reported by ${ }^{23}$, where Gram-negative bacteria made up of $81 \%$ of lampenflora in Magura Cave, Bulgaria. Subterranean caves are characterized by almost stable temperature with high humidity and these factors favor the growth of heterotrophic bacteria, from which actinomycetes predominate ${ }^{24}$. In some cases, Streptomyces species are particularly found to be abundant.

The two species of bacteria, $P$. aeruginosa and Stenotrophomonas sp. and the three species of yeasts $P$. guilliermondii, $C$. liquefaciens and $R$. dairenesis, based on the dry weight and cell enumeration of Synechococcus sp. and Micractinium sp. showed that these microorganisms were able to grow together. This shows that no matter how varied the conditions inside the caves, these microorganisms thrive in their natural growth ${ }^{23,25}$.

The bacteria recorded in the Tempurung and Niah Caves, partly corresponded to the species found in other caves such as Leontari Cave, Ponikve cave, Sybil" s cave, bat-inhabited cave in Japan, and Magure cave $\mathrm{e}^{25-28}$.

Cave is one of the environments with the factors that make the cave a unique environment: 1) the absence of sunlight, 2) the stability of the microclimate of the cave because of the surrounding rock layer which isolated the cave from the external weather conditions, 3) rich in nutrients contributed by guano, birds and animal droppings that support the growth of lampenflora. Some microflora grows on wood, animal bones and on the cave walls, ceiling and floor. These organisms thrive in this environment, particularly in the caves with artificial illumination. High levels of phosphorus and nitrogen in guano, high humidity in the range of $85 \%$ to 98\% and sufficient light whether natural or artificial, enhance the colonization and growth of microorganisms such as bacteria, cyanobacteria and protozoa ${ }^{2,29}$. 
The results showed that treatment with 5\% concentration of sodium hypochlorite $(\mathrm{NaOCl})$ effectively eliminated colonies/cells of bacteria compared to the colonies found on the control pate this study, 30 minute treatment with $15 \%$ $\mathrm{NaOCl}$ concentration was enough to eliminate the entire lampenflora isolated. Treatment with $5 \% \mathrm{NaOCl}$ concentration was enough to destroy Stenotrophomonas sp. and Cryptococcus liquefaciens. According to a study conducted by ${ }^{30}, \mathrm{NaOCl}$ was proven to be an efficient biocide. Similar results were also reported by ${ }^{20}$, where $\mathrm{NaOCl}$ at concentrations of $5 \%$ and $10 \%$ were extremely effective in eliminating the lampenflora tested. ${ }^{30}$ and ${ }^{31}$ also found that $5 \%$ of $\mathrm{NaOCl}$ was sufficient to destroy the entire lampenflora. Based on the present and previous results reported, $\mathrm{NaOCl}$ (even at the lower concentration) is recommended as an effective disinfectant. In the present study, $5 \%$ concentration of $\mathrm{H}_{2} \mathrm{O}_{2}$ reduced the number of cells

\section{REFERENCES}

1. Harrison T. The palaeoecological context at Niah cave, Sarawak: Evidence from primate fauna, Indo-Pacific prehistory association bulletin. 1996; 14:90-100

2. Mulec J. Microorganisms in hypogeon: examples from slovenian karst caves, Acta carsologica, 2008; 37:153-160.

3. Ahmed T, Shimizu TS, and Stocker R. Microfluidics for bacterial chemotaxisw, The Royal Society of Chemistry. 2010; 2(11-12):604629 .

4. Ercole C, Cacchio P, Cappuccio G, and Lepidi A. Deposition of calcium carbonate in karst caves role of bacteria in stiffe's cave, International Journal of Speleology, 2001; 30:69-79.

5. Rajendran R. and Prasad NA study on the indoor and outdoor microflora associated with the biodeterioration of mural paintings at Sekharaipuram Vishnu temple, Adakkaputhur, Palakkad, Kerala, India International Journal of Environmental Sciences and Research. 2012; 1(4):104-108

6. Adetutu EM, Thorpe K, Shahsavari E, Bourne S, Cao X, and Fard RMN. Bacterial community survey of sediments at Naracoorte Caves, Australia International Journal of Speleology. 2012; 4:137-147.

7. Valdez H, and Salata A. Bat-associated histoplasmosis in returning travelers: case presentation and description of a cluster, Journal of Travel Medicine. 1999; 6:258-260.

8. Heyrman J, Balcaen A, Rodriguez-Diaz M, Logan N A, Swings J. and Vos P D. Bacillus decolorationis sp. nov., isolated from biodeteriorated parts of the mural paintings at the Servilia tomb (Roman necropolis of Carmona, Spain) and the Saint-Catherine chapel (Castle Herberstein, Austria), International Journal of Systematic and Evolutionary Microbiology. 2003; 53:459-463.

9. Bahig AE, Aly EA, Khaled AA, and Amel KA. Isolation, characterization and application of bacterial population from agricultural soil at Sohag Province, Egypt.," Malaysian Journal of Microbiology. 2008; 4:42- 50.

10. Andersen R, and Kawachi M. Traditional Microalgae Isolation Techniques In: Andersen, R. (eds) Algel Culturing Techniques, Academic Press, UK. 2005; 83-100.

11. Smith GM. The fresh water algae of the United States. New York Toronto London McGraw-Hill book company. 1950; 537-725.

12. Ahmed ZU, Khondker M, Begum ZNT, Hassan MA, Kabir S , and Ahmad M. Encyclopedia of flora and fauna of bangladesh bangladesh. 1952; 508-543

13. Prescott GW. Algae of the western great lakes area with an lllustrated key to the genera of desmids and freshwater diatoms $U . S . A$ : WM. C. Brown Company Publishers.1962.

14. Brock TD, Madigan MT, Martinko JM, and Parker J. Biology of microorganisms seventh edition prentice hall Englewood cliffs new jersey. 1994; 897-909.

15. Al-Fawwaz A T S. Biosorption of heavy metals from aqueous solutions by green algae isolated from rivers in Penang, Malaysia. $\mathrm{PhD}$ Thesis, Universiti Sains Malaysia, Penang, Malaysia. 2010; 183. of Stenotrophomonas sp. The result by ${ }^{32}$, who found that at $5 \%$ concentration of $\mathrm{H}_{2} \mathrm{O}_{2}$ was enough to eliminate their entire lampenflora in the laboratory. Calcium hypochlorite $\mathrm{Ca}(\mathrm{OCl})_{2}$ was effective in eliminating all the microorganisms tested. The results showed that treatment with 5\% concentration of $\mathrm{Ca}(\mathrm{OCl})_{2}$ was enough to reduce and eliminate Stenotrophomonas sp. and C. liquefaciens. Fifteen percent concentration of $\mathrm{Ca}(\mathrm{OCl})_{2}$ effectively eliminated Stenotrophomonas sp. at the first few minutes of exposure. These results support the previous report by ${ }^{20}$ whereby calcium hypochlorite was effective in eliminating the lampenflora at low concentrations $(5 \%, 10 \%)$.

However, the treatment with $\mathrm{Ca}(\mathrm{OCl}) 2$ and $\mathrm{NaOCl}$ may be accompanied by some problems such as the smell of chlorine or problem of percolation and explosive reaction with ammonia, amines or organic sulphides; although it is considered a good chemical to eliminate the bacteria.

16. Nishiguchi MK, Doukakis P, Egan M, Kizirian D, Phillips A, and Prendini L. et al. DNA Isolation Procedures Switzerland. 2002; 287.

17. Shahriar M, Haque M R, Kabir S, Dewan I, and Bhuyian M A. Effect of Proteinase-K on Genomic DNA Extraction from Gram-positive Strains Stamford, Journal of pharmaceutical Sciences. 2011; 4:53-57.

18. Eliopoulos GM, and Eliopoulos, CT. Antibiotic combinations: should they be tested. Clinical microbiology. 19881; (2)139-156.

19. Michael E, Klepser EJE, Russell E, Lewis Michael E. Ernst, \& Pfaller M A. "Influence of test conditions on antifungal time-kill curve results: proposal for standardized methods. Antimicrob agents chemother. 1998; 42(5):1207-1212.

20. Iliopoulou-Georgoudaki J, Pantazidou A. and Theoulakis P. an assessment of cleaning photoautotropic micro lora: the case of "perama" cave, ioannina greece. Memoires e biospeologie, tome xx. 1993; 117-120.

21. Grobbelaar J U. Lithophytic algae: A major threat to the karst formation of show caves. Journal of Applied Phycology. 2000; 12:309315.

22. Hoffmann L. Algae of terrestrial habitats. Botanical Review. 1989; 55:77-105

23. Tomova I, Lazarkevich I, Tomova A, Kambourova M, and VasilevaTonkova E. Diversity and biosynthetic potential of culturable aerobic heterotrophic bacteria isolated from Magura Cave, Bulgaria, International Journal of Speleology, 2013; 42:65-76.

24. Groth I, and Saiz-Jimenez C, Actinomycetes in hypogean environments. Geomicrobiol, Journal Citation Reports, 1999; 16:1-8.

25. Sugita T, Kikuchi K, Makimura K, Urata K, Someya T, and Kamei K et al. Trichosporon Species Isolated from Guano Samples Obtained from Bat-Inhabited Caves in Japan, Applied Environ Microbiol, 2005; 71:7626-7629.

26. Garbacki N, Ector L, Kostikov I, and Hoffmann L. Contribution a` l"e'tude de la flore des grottes de Belgique Belgian, Journal of Botany, 1999; 132:43-76.

27. Smith T, and Olson RA. Taxonomic Survey of Lamp Flora (Algae and Cyanobacteria) in Electrically Lit Passages within Mammoth Cave National Park, Kentucky., International Journal of Speleology. 2007; 36:105-114.

28. Cennamo, Marzano P, Ciniglia C, Pinto C, Cappelletti G, Caputo P, et al. A survey of the algal flora of anthropogenic caves of campi flegrei (naples, italy) archeological district. Journal of cave and karst studies, 2011; 74(3):243-250.

29. Czerwik-Marcinkowska J, and Mrozińska T. Algae and cyanobacteria in caves of the polish jura. Polish Botanical Journal, 2011; 56(2):203243.

30. Mulec JA, and Kosi G. lampenflora algae and methods of growth control. Journal of cave and karst studies, 2009; 71(2):109-115.

31. Cigna AA. "Show cave development with special references to active caves. Sociedade Brasileira de Espeleologia, 2011; 4(1)16.

32. Faimon J, Sctelcl J, Kubesova S, \& Zimak J, "Environmentally acceptable effect of hydrogen peroxide on cave "lamp-flora", calcite speleothems and limestones. Environmental Pollution, 2003; 122(3):417-422. 